\title{
Evaluation of professional knowledge and attitudes on dementia patient care: a trans-cultural adaptation of an evaluation instrument
}

\author{
Avaliação de conhecimentos e atitudes profissionais no cuidado às \\ demências: adaptação transcultural de um instrumento \\ Evaluación de conocimientos y actitudes profesionales en el cuidado \\ a las demencias: adaptación transcultural de un instrumento
}

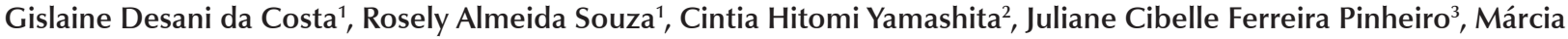
Regina Martins Alvarenga ${ }^{4}$, Maria Amélia de Campos Oliveira ${ }^{5}$

\footnotetext{
* Extracted from the Master's dissertation entitled "Adptação transcultural do instrumento Atenció Sanitària de Les Demències: la visió de L'Atenció Primarià," School of Nursing, Universidade de São Paulo, 2014.

${ }^{1}$ Master in Nursing from the School of Nursing Graduate Program, University of São Paulo, São Paulo, SP, Brazil.

${ }^{2}$ Current $\mathrm{PhD}$ candidate from the School of Nursing Graduate Program, University of São Paulo, São Paulo, SP, Brazil.

${ }^{3}$ Nurse from the Nursing School of Coimbra, Coimbra, Portugal

${ }^{4}$ Adjunct Professor in the Undergraduate Nursing Program, Mato Grosso do Sul State University, Dourados, MS, Brazil.

${ }^{5}$ Full Professor, Department of Nursing in Public Health, São Paulo University School of Nursing, São Paulo, SP, Brazil.
}

\section{ABSTRACT}

Objective: To describe the trans-cultural adaptation of the evaluation instrument entitled Atenció Sanitària de Les Demències: la visió de L'Atenció Primarià from Catalan into versions in Portuguese for doctors and nurses. This study evaluates the knowledge and perspectives of these professionals in their treatment of patients diagnosed with dementia in cases of primary care. Method: The adaptation followed internationally accepted rules, which include the following steps: translation, synthesis, back-translation, revision by a committee of specialists, and a test run with 35 practicing doctors and 35 practicing nurses in Brazil's Family Health Strategy (Estratégia Saúde da Família, or ESF in Portuguese). Results: The translation, synthesis, and back-translation steps were performed satisfactorily; only small adjustments were required. The committee of specialists verified the face validity in the version translated into Portuguese, and all of the items that received an agreement score lower than $80 \%$ during the initial evaluation were revised. In the test run, the difficulties presented by the health care professionals did not reach $15 \%$ of the sample, and therefore, no changes were made. Conclusion: The Portuguese translation of the instrument can be considered semantically, idiomatically, culturally, and conceptually equivalent to the original Catalan version and is, therefore, appropriate for use in Brazil.

\section{DESCRIPTIORS}

Dementia; Aged; Primary Health Care; Health Personnel; Cross-Cultural Comparison.
Corresponding author:

Gislaine Desani da Costa

Av. Dr. Enéas de Carvalho de Aguiar, 419 - Cerqueira

Cesar CEP 05403-000 - São Paulo, SP, Brazil

gislaine.desani@usp.br
Received: 10/31/2014

Approved: 12/04/2014 


\section{INTRODUCTION}

The demographic shifts in the past few decades witnessed around the world include dramatic changes in average population age and life expectancy. In Brazil, life expectancy increased from 48.9 years to 75.0 years from 1960 to 2012 , respectively, in just over half a century ${ }^{(1-2)}$. The country's fertility rate, which was 2.4 children per woman in 2000 , has continued to decrease and reached 1.8 between 2002 and $2006^{(3)}$. These changes, which have occurred in parallel with technological advances, have led to a narrower base in the Brazilian age pyramid and a wider top section; this reflects the structure of an aging population, common in developed countries ${ }^{(2)}$.

Projections estimate that the population over 60 years of age is likely to rise from 14.9 million $(7.4 \%$ of the total population) in 2013 to 58.4 million (26.7\% of the total population) in 2060. During the same period, average life expectancy in Brazil is likely to increase from 75 years to 81 years of age ${ }^{(1)}$. The age cohort that will experience the most expansion will be the 80 years and older group ${ }^{(4-5)}$.

It is worrisome that living longer contributes to the decline of physiological functions and increases the probability of chronic neuro-degenerative diseases, including dementia. These diseases can lead to different degrees of physical and mental incapacity and can present many challenges for both the families of the elderly and Brazilian society as a whole ${ }^{(6-7)}$.

Currently, the number of people living with dementia worldwide is estimated to be 35.6 million. This number is expected to double by 2030 and triple by $2050^{(7)}$. From a clinical perspective, little can be done to prevent or revert cases of dementia. At most, doctors can slow its evolution when the diagnosis is made in the early stages. As the disease progresses, the person affected by it becomes increasingly dependent upon care from family members ${ }^{(8)}$.

Caring for people with dementia is a significant burden for those who undertake this responsibility. The patient's behavioral issues can lead to cases of depression and anxiety in caregivers and may even cause their own health to decline. Knowing how to recognize the symptoms of the disease may help reduce tensions between the caregiver and the patient. Thus, it may improve care and, consequently, the quality of life of both patient and caregiver ${ }^{(9)}$.

In Brazil, the tracking of dementia cases is addressed in the Guidelines for Basic Elderly Health Care: Aging and Elder Health (Caderno de Atenção Básica à Saúde do Idoso: Envelhecimento e Saúde da Pessoa Idosa in Portuguese). These guidelines recommend that a senior citizen with a possible memory disorder undergo clinical and cognitive examinations to exclude potentially irreversible types of dementia. Once these types are excluded, monitoring is recommend$\mathrm{ed}^{(10)}$. However, these examinations are rarely performed as part of basic care in Brazil. Many professionals report that they do not feel prepared, that they have not received the necessary training to appropriately deal with these cases, or that they do not have time for the clinical investigation required $^{(11)}$.
Many studies have been performed to evaluate the knowledge and perspectives of professionals in primary care involved in treating patients with dementia $(12-20)$ One of the strategies used was the application of questionnaires in their workplaces. Among the questionnaires available, one instrument in Catalan deserves special attention: the Atenció Sanitària de Les Demències: la visió de $L^{\prime}$ Atenció Primaria ${ }^{(14)}$. Its approach to the topic is very complete and it is available in two versions: one for doctors and another for nurses.

For years, Catalonia (the Spanish autonomous community, the capital of which is Barcelona) has faced progressive aging of its population; Brazil is now beginning to experience similar challenges. Due to these changes, Catalonia's public health system has had to adapt itself to respond to the specific health needs of its population.

To formulate a protocol for cases of suspected clinical cognitive impairment, the Catalan Society of Family and Community Medicine developed a questionnaire to better understand the needs of medical professionals working in primary care so that these professionals can better diagnose, treat, and monitor patients suffering from dementia and their families ${ }^{(14)}$

In both the doctors' and the nurses' version, the original instrument contains both open and closed questions. The questions are self-explanatory and can be answered independently. They consider the monitoring, diagnosis, and follow-up of patients with dementia. The closed questions include multiple-choice questions, classification questions, and others with a limited number of response options from which the professional can only choose one. There are no wrong answers, since the inquiry solicits the opinions of professionals about the procedures involved in their daily clinical practices. The goal of the inquiry is to better understand the treatment that patients with dementia receive.

The goal of this study was to adapt for use both the doctors' and the nurses' version of the instrument. Once adapted, it will provide an insight into the perspectives of the health care professionals involved in the primary health care of patients with dementia in Brazil. The results can aid in the development of qualification programs that will, in turn, make it possible for these health professionals to offer a better quality of care to patients and their families.

\section{METHOD}

Both the doctors' and nurses' versions of the inquiry instrument were adapted according to the protocol of international trans-cultural rules for adopting evaluation instruments ${ }^{(21)}$. To perform this adaptation, a translation, synthesis, back-translation, review by a committee of specialists (judges), and a test run were conducted.

\section{Initial Translation into Portuguese}

In the first stage, the instruments were translated into Brazilian Portuguese. Independent translations (T1 and T2) were performed by two bilingual translators whose first language is Portuguese and who are fluent in Catalan. The 
first translator, who was an expert in medical translation, received information on the objectives and concepts involved in the instruments. The second translator did not share this specialty and did not receive this information.

\section{TransLATION SyNTHESIS}

After T1 and T2 were completed, the researchers involved held a meeting to synthesize the translations and a single common translation (T3) was developed. T3 was approved by both the original translators.

\section{Back-Translation}

T3 was then translated back into its original language (Catalan) by two bilingual translators who were not from the health field and whose first language was Catalan. This task resulted in two back-translations (BT1 and BT2). In this stage, the translators did not receive any information about the objectives or concepts involved in the instruments.

To confirm that the back-translations contained the same content as the original version, a native Catalan speaker working as a translator in Brazil was asked to evaluate the work. This translator confirmed that the meaning of the original instruments had been maintained, and no further revisions were necessary.

\section{Revision by a Committee of Judges (Face Validity)}

In this stage, T3 (which was accompanied by the original instruments, along with T1, T2, BT1, and BT2) was submitted for analysis to a committee of judges specialized in the topic at hand. The committee comprised five doctors and five nurses, each of whom focused on their respective version. Almost all of the judges were bilingual and experienced in trans-cultural adaptation of instruments.

The judges' review focused on the differences between the translation and its practical use, a factor which can be characterized as face validity ${ }^{(22)}$. First, each judge evaluated the instrument independently. The following factors were evaluated: semantic equivalence, which refers to the consistency in the meaning of the words and the correct translations of the items and concepts; idiomatic equivalence, or the use of consistent idiomatic or colloquial expressions between the two languages; cultural equivalence, or the coherence between the daily experiences and culture of the two countries involved; and conceptual equivalence, which refers to the consistency between the concepts proposed in the original instrument and the translated instrument ${ }^{(21)}$.

The items were evaluated using an equivalency scale with the following classifications: -1 (not equivalent); 0 (unclear); and +1 (equivalent) ${ }^{(23)}$. The content that was classified by the committee members as not equivalent $(-1)$ or unclear (0) were revised until the specialists reached at least an $80 \%$ consensus rate ${ }^{(23-24)}$. Both versions of the instrument were also reviewed by a sixth judge, a Brazilian Portuguese editor, who revised the written language of the document.

After the judges' initial evaluation, three meetings were held with the group to discuss the issues and to select the terms that would be most appropriate for Brazilian culture.
It is important to note that not all judges were able to attend all of the meetings. They received a summary of the discussion and comments via e-mail so they could be involved in the final decision-making. Thus, at least an $80 \%$ consensus was reached among the judges, and the pre-final version of the instruments was ready for the test run in the field.

\section{Test Run}

For the test run, the final stage of the trans-cultural adaptation process, the pre-final versions of the instruments were given to 35 practicing doctors and 35 practicing nurses from the Primary Health Care Units (Unidades Básicas de Saúde, or UBS in Portuguese) of Brazil's Family Health Strategy. The institutions involved belong to the Southern Regional Health Care District and to the Santo Amaro/Cidade Ademar Health Care Technical Supervision Department of the city of São Paulo, in São Paulo State.

Each participant received a printed version of the prefinal instrument. They were asked if they understood the wording of the questions and the possible responses and were encouraged to express any doubts. If $15 \%$ or more of the participants had difficulty understanding a question, a revision would be considered. This stage produced the final Portuguese versions of the instruments.

\section{Data Analysis}

To create and develop the database, as well as to perform the statistical analysis, Microsoft Office ${ }^{\circledR}$ Excel $^{\circledR}$ and the Statistical Package for the Social Sciences (SPSS ${ }^{\circledR}$ ), version 20.0 for Windows, were used. The descriptive statistical analysis was performed to characterize the subjects, to verify the face validity of the adapted instruments, and to determine the results of the test run.

\section{Ethical Considerations}

The study was approved by the Committee of $\mathrm{Re}$ search Ethics of the University of São Paulo (number 252.904/2013) and the São Paulo Municipal Department of Health (number 255.857/2013). All of the participants signed a free and clarified consent form (TCLE, in Portuguese). The main author of the original instruments authorized the adaptation.

\section{RESULTS}

The cultural adaptation process took one year. T1 and T2 of the instruments were similar; the version from Translator 1 was more representative of Brazilian Portuguese and more formal than the version from Translator 2. Small adjustments were necessary during the researchers' meeting to generate the final synthesized translation (T3). BT1 and BT2 were satisfactorily produced. It was confirmed that the meaning of the original instruments was maintained in the translations.

As for the evaluation by the judges' committee, the results of the equivalency scales among the five doctors and five nurses are presented in Table 1. 
Table 1- Indices of agreement among the judges, according to the evaluations of semantic, idiomatic, cultural, and conceptual equivalence between the original and translated versions of the instrument Atenció Sanitària de Les Demències: la visió de L'Atenció Primarià, with a doctors' and a nurses' version, in São Paulo, 2014.

\begin{tabular}{|c|c|c|c|c|}
\hline Item & $\mathrm{SE}^{\mathrm{a} \%}$ & IE $^{\mathrm{b}} \%$ & $\mathrm{CuE}^{\mathrm{c}} \%$ & $\operatorname{CoE}^{\mathrm{d} \%}$ \\
\hline \multicolumn{5}{|l|}{ Doctors' Version } \\
\hline Guidelines for how to use the instrument & 100 & 60 & 100 & 100 \\
\hline Questions 1, 3, 4, 9, 15, 18, 21a, 22, 25, 26 and 27 & 100 & 100 & 100 & 100 \\
\hline Question 2 & 100 & 100 & 0 & 100 \\
\hline Questions 5, 8, 10, 11, 24 and 28 & 100 & 100 & 60 & 100 \\
\hline Questions 6 and 7 & 100 & 20 & 100 & 100 \\
\hline Questions 12 and 14 & 60 & 60 & 100 & 100 \\
\hline Questions 13, 19, 21 and 23 & 100 & 60 & 60 & 100 \\
\hline Question 16 & 80 & 20 & 20 & 40 \\
\hline Question 17 & 100 & 40 & 40 & 60 \\
\hline Question 20 & 60 & 60 & 60 & 60 \\
\hline Average & 95.3 & 79.3 & 78.7 & 95.3 \\
\hline \multicolumn{5}{|l|}{ Nurses' Version } \\
\hline Guidelines for how to use the instrument & 60 & 60 & 100 & 80 \\
\hline Questions 1, 14a and 15 & 100 & 80 & 100 & 100 \\
\hline Question 2 & 100 & 80 & 40 & 100 \\
\hline Question 3 & 80 & 80 & 100 & 100 \\
\hline Question 4 & 100 & 100 & 100 & 80 \\
\hline Question 5 & 100 & 60 & 40 & 60 \\
\hline Question 6 & 100 & 60 & 40 & 80 \\
\hline Question 7 & 80 & 80 & 60 & 100 \\
\hline Question 8 & 100 & 100 & 60 & 100 \\
\hline Question 9 & 100 & 80 & 60 & 80 \\
\hline Question 10 & 100 & 80 & 60 & 100 \\
\hline Question 11 & 100 & 60 & 100 & 80 \\
\hline Question 12 & 100 & 80 & 20 & 80 \\
\hline Question 13 & 100 & 100 & 100 & 60 \\
\hline Question 14 & 100 & 60 & 80 & 100 \\
\hline Question 16 & 100 & 60 & 100 & 60 \\
\hline Average & 95.6 & 76.7 & 75.6 & 86.7 \\
\hline
\end{tabular}

aSE: Semantic Equivalence; ' ${ }^{\mathrm{l} E}$ : Idiomatic Equivalence; ${ }^{\mathrm{C} C u E:}$ Cultural Equivalence; ${ }^{\mathrm{d}} \mathrm{CoE}$ : Conceptual Equivalence.

The items with results below $80 \%$ were reviewed and modified according to the suggestions from the judges. A1most all of the items received grammatical changes from the Brazilian Portuguese editor. In the second evaluation, after the alterations proposed by the judges' committee and the Portuguese editor were implemented, a consensus of above $80 \%$ was reached for all of the evaluated items. The Portuguese name that the judges proposed for the instrument was Atenção Sanitária às Demências: a visão da Atenção Básica (Health Care for Dementia Patients: the primary health care perspective).

In the test run, the professionals involved were predominantly female $(65.7 \%$ of the doctors and $94.3 \%$ of the nurses). The doctors averaged 38.6 years of age ( $\mathrm{SD}=$ 10.0 ; median $=35.0$ ), and the nurses averaged 36.1 years of age $(\mathrm{SD}=5.9$; median $=36)$. The doctors' time of employment in Primary Health Care Units averaged 89.2 months
$(\mathrm{SD}=89.8 ;$ median $=60.0)$, while the nurses' time of employment averaged 87.0 months $(\mathrm{SD}=42.3$; median $=84.0$ ).

At this point, the problems were limited to difficulties in answering questions where a series of factors had to be identified and classified according to importance, from most important to least important (two doctors and four nurses reported this problem). When they were advised to re-read the instructions on the use of the instrument, one nurse still had questions that were resolved by a verbal explanation from the interviewer. Because these difficulties were not experienced by $15 \%$ or more of the professionals sampled, no changes were made.

However, six professionals (17.1\%) reported feeling the need for another alternative in $14 \mathrm{a}$, which considers the reasons for their difficulties in caring for patients with advanced stages of dementia. Thus, the answer choice "other" was added to the question. For the sake of consistency, the 
same alteration was also added to question 21 a of the doctors' version of the questionnaire. The Brazilian Portuguese versions of the instruments can be found in the Appendix.

\section{DISCUSSION}

The trans-cultural adaptation of instruments has been employed frequently in recent years due to the growing trend of multi-center studies and the important cultural differences among countries. Through this adaptation, the object being studied can be compared among countries or among people of different origins in the same country 21 .

Many authors have dedicated their work to the construction of systematic methods of trans-cultural adaptations that would allow for the measurement of a given phenomenon in different cultures. To preserve the conceptual significance of a questionnaire or instrument, a good linguistic translation is not enough; the translation should also consider the culture and the lifestyle of the population which will receive the new version ${ }^{(21)}$.

In this study, the trans-cultural adaptation process strictly followed the recommendations established by the protocol $^{(21)}$. It is important to note that no other cultural adaptation studies of the instrument Atenció Sanitària de Les Demències: la visió de L'Atenció Primarià was found in doctors' or nurses' versions in any other languages or cultures.

The face validity allowed for the evaluation of the "degree to which each element of the instrument is relevant and representative of a specific construct and with a particular evaluation purpose" ${ }^{(22)}$. This validity can be established by a committee of specialists from the area of the questionnaire. For the judges to perform a good initial independent evaluation, they should first be provided specific instructions on how to evaluate each item and the instrument as a whole, as well as how to fill out the form that will guide the evaluation and only then should they meet with other committee members. In this study, each of these steps was followed. In this way, the meeting will allow for the judges to resolve the contentious points observed during the initial assessment ${ }^{(22)}$. Many other studies have relied on the method used in this study to guarantee the face validity ${ }^{(25-27)}$.

The judges considered the instruments to be culturally relevant for medical practice in Brazil. According to the committee, "the specialized services available have not responded to the demand for dementia treatment that has come about as a result of the increase in life expectancy." It worries them that patients do not seek out health care services until the disease has reached an advanced stage.

It is important to note that, in the Brazilian version of the instrument, the term "basic care" was adopted rather than "primary care" because the term "basic care" is used in Brazilian health care system as a different concept than primary care. In the 1980 s, the idea of primary care had assumed "the character of a simplified health care program for the poor in rural and urban areas, rather than a strategy for the reorganization of the health services system" ${ }^{28)}$.

As part of the country's basic care policy, primary health care services were developed with a high degree of decentralization, and therefore, it became many patients' first contact with the system. Therefore, the data obtained these services must be communicated to the entire health care network. The main element of the policy is Brazil's Family Health Strategy, the goal of which is to treat the registered population in the areas covered and to refer patients to other practices, depending on the health care needs of the individuals and their families ${ }^{(29)}$. In this situation, better training for the doctors and nurses working in primary care may contribute to more opportune diagnoses of the different types of dementia, or, ideally, to institute proper treatment while the disease is still in its early stages.

The test run, which was the final stage in the adaptation process, provided important information on how people interpret the items in the questionnaire, how to think of ways to resolve the different interpretations of the questions, and whether to include necessary items that complement the health professionals' experiences. In the end, all of the stages of the protocol ${ }^{(21)}$ were completed.

A limitation of the study is the fact that the translators who performed the initial translations and back-translations were not able to participate in the judges' committee because of scheduling conflicts.

The cultural adaptation process assures only face validity; therefore, additional tests to evaluate the psychometric properties of the items (such as reliability) using stability evaluations (test-retest) and convergent validity should be performed.

\section{CONCLUSION}

The doctors' and nurses' versions of the inquiry instrument known as the Atenció Sanitària de Les Demències: la visió de L'Atenció Primarià, was satisfactorily adapted for use with the Brazilian population. The Brazilian Portuguese version was observed to maintain the semantic, idiomatic, cultural, and conceptual equivalence of the items translated from the original version in Catalan. The name given in Portuguese was Atenção Sanitária às Demências: a visão da Atenção Básica. It includes 28 questions in the doctors' version and 16 questions in the nurses' version, just as in the original. 'Both versions are self-explanatory and can be completed independently.

\section{RESUMO}

Objetivo: Descrever o processo de adaptação transcultural do instrumento Atenció Sanitària de Les Demències: la visió de L'Atenció Primarià, em suas versões para médicos e enfermeiros, utilizado para avaliar o conhecimento e as atitudes desses profissionais no atendimento às demências na Atenção Primária. Método: A adaptação seguiu normas internacionalmente aceitas, com as seguintes etapas: tradução, síntese, retrotradução, revisão por um comitê de especialistas e pré-teste com 35 médicos e 35 enfermeiros atuantes na Estratégia Saúde da Família. Resultados: As etapas de tradução, síntese e retrotradução foram realizadas a contento, sendo necessários pequenos ajustes. 
O comitê de especialistas verificou a validade de conteúdo da versão traduzida e todos os itens que obtiveram concordância inferior a $80 \%$ na avaliação inicial foram revistos. No pré-teste, as dificuldades apresentadas pelos profissionais não atingiram $15 \%$ da amostra, não sendo objeto de alteração. Conclusão: $\mathrm{O}$ instrumento traduzido alcançou equivalências semântica, idiomática, cultural/experimental e conceitual, podendo ser usado na realidade brasileira.

\section{DESCRITORES}

Demência; Idoso; Atenção Primária à Saúde; Pessoal de Saúde;Comparação Transcultural.

\section{RESUMEN}

Objetivo: Describir el proceso de adaptación transcultural del instrumento Atenció Sanitària de Les Demències: la visió de L'Atenció Primarià, en sus versiones para médicos y enfermeros, utilizado para evaluar el conocimiento y las actitudes de dichos profesionales en la atención a las demencias en la Atención Primaria. Método: La adaptación siguió normas internacionalmente aceptadas, con las siguientes etapas: traducción, síntesis, retrotraducción, revisión por un comité de expertos y pre prueba con 35 médicos y 35 enfermeros actuantes en la Estrategia Salud de la Familia. Resultados: Las etapas de traducción, síntesis y retrotraducción fueron llevadas a cabo satisfactoriamente, siendo necesarios pequeños ajustes. El comité de expertos verificó la validez de contenido de la versión traducida, y todos los puntos que lograron concordancia inferior al $80 \%$ en la evaluación inicial fueron revistos. En la pre prueba, las dificultades presentadas por los profesionales no alcanzaron el 15\% de la muestra, no siendo objeto de alteración. Conclusión: El instrumento traducido alcanzó equivalencia semántica, idiomática, cultural/experimental y conceptual, por lo que se puede emplearlo en la realidad brasileña.

\section{DESCRIPTORES}

Demencia; Anciano; Atención Primaria de Salud; Personal de Salud; Comparación Transcultural.

\section{REFERENCES}

1. Instituto Brasileiro de Geografia e Estatística. Censo 2010: características gerais da população, religião e pessoas com deficiência [Internet]. Rio de Janeiro: IBGE; 2010 [citado 2012 jun. 29]. Disponível em: http://biblioteca.ibge.gov.br/visualizacao/periodicos/94/cd_2010_religiao_deficiencia.pdf

2. Instituto Brasileiro de Geografia e Estatística. Projeção da população das Unidades da Federação por sexo e idade $2000-2030$ [Internet]. Rio de Janeiro: IBGE; 2013. [citado 2013 dez. 09]. Disponível em: http://www.ibge.gov.br/home/estatistica/populacao/projecao_da_populacao/2013/default.shtm

3. Brasil. Ministério da Saúde; Centro Brasileiro de Análise e Planejamento. Pesquisa Nacional de Demografia e Saúde da Criança e da Mulher - PNDS 2006: dimensões do processo reprodutivo e da saúde da criança [Internet]. Brasília; 2009 [citado 2012 nov. 26]. Disponível em: http://bvsms.saude.gov.br/bvs/publicacoes/pnds_crianca_mulher.pdf

4. Fundo de População das Nações Unidas. Relatório sobre a situação da população mundial: pessoas e possibilidades em um mundo de 7 bilhões [Internet]. 2011 [citado 2012 nov. 26]. Disponível em: http://portaldoenvelhecimento.org.br/uploads/images/janeiro2012/Pessoase-possibilidades-em-um-mundo-de-7-bilhoes\%20.pdf

5. Camarano AA. Cuidados de longa duração para a população idosa: um novo risco social a ser assumido? Rio de Janeiro: IPEA; 2010.

6. Burlá C, Camarano AA, Kanso S, Fernandes D, Nunes R. Panorama prospectivo das demências no Brasil: um enfoque demográfico. Ciênc Saúde Coletiva. 2013;18(10):2949-56.

7. World Health Organization. Dementia: a public health priority [Internet]. Geneva; 2012 [cited 2012 June 20]. Available from: http:// whqlibdoc.who.int/ publications/2012/9789241564458_eng.pdf

8. Abdollahpour I, Noroozian M, Nedjat S, Majdzadeh R. Caregiver burden and its determinants among the family members of patients with dementia in Iran. Int J Prev Med. 2012;3(8):544-51.

9. Joanna Briggs Institute. Assisting caregivers to support people with dementia: evidence-based information sheets for health professionals. Best Pract. 2010;14(9):1-4.

10. Brasil. Ministério da Saúde; Secretaria de Atenção à Saúde, Departamento de Atenção Básica. Envelhecimento e saúde da pessoa idosa. Brasília; 2006.

11. Blay SL. Epidemiologia dos transtornos psiquiátricos na velhice. In: Tavares A, editor. Compêndio de neuropsiquiatria geriátrica. Rio de Janeiro: Guanabara Koogan; 2005. p. 97-108.

12. Buhagiar K, Afzal N, Cosgrave M. Behavioural and psychological symptoms of dementia in primary care: a survey of general practitioners in Ireland. Ment Health Fam Med. 2011; 8(4):227-34.

13. Poltroniere S, Cecchetto FH, Souza EN. Doença de Alzheimer e demandas de cuidados: o que os enfermeiros sabem? Rev Gaúcha Enferm. 2011;32(2):270-8.

14. Tuero GC, Garre-Olmo J, Lòpez-Pousa S, et al. Percepción, actitudes y necesidades de los profesionales de atención primaria con relación al paciente con demencia. Aten Primaria. 2011;43(11):585-94.

15. Ahmad S, Orrell M, Iliffe S, Gracie A. GPs' attitudes, awareness, and practice regarding early diagnosis of dementia. Br J Gen Pract. 2010;60(578):360-5.

16. Baloch S, Moss SB, Nair R, Tingle NRL. Practice patterns and management of dementia in primary care residents, primary care physicians and geriatricians. Proc (Bayl Univ Med Cent). 2010;23(2):121-5.

17. Parmar J, Dobbs B, McKay R, Kirwan C, Cooper T, Marin A, et al. Diagnosis and management of dementia in primary care: exploratory study. Can Fam Physician. 2014;60(5):457-65. 
18. Van den Dungen P, Van Marwijk HW, Van der Horst HE, Moll van Charante EP, Macneil Vroomen J, van de Ven PM, et al. The accuracy of family physicians' dementia diagnoses at different stages of dementia: a systematic review. Int J Geriatr Psychiatry. 2012;27(4):342-54.

19. Hausner L, Damian M, Jekel K, Richter M, Frölich L. Attitudes toward dementia management in Germany: data from the impact survey (important perspectives on Alzheimer's care and treatment. Dtsch Med Wochenschr. 2012;137(25-26):1351-5.

20. Martín-Carrasco M, Arranz FJ. Perspectives of Spanish psychiatrists on the management of dementias: the PsicoDem survey. Rev Psiquiatr Salud Ment. 2014;9(14):1-9.

21. Beaton DE, Bombardier C, Guillemin F, Ferraz MB. Guidelines for the process of cross-cultural adaptation of self-report measures. Spine. 2000;25(24):3186-91.

22. Alexandre NMC, Colluci MZO. Validade de conteúdo nos processos de construção e adaptação de instrumentos de medidas. Ciênc Saúde Coletiva. 2011;17(7):3061-8.

23. Nunnally JC, Bernstein IH. Psychometric theory. 30th ed. New York: McGraw Hill; 1994.

24. Waltz CF, Strickland OL, Lenz ER. Measurement in nursing research. 2nd ed. Philadelphia: F.A. Davis; 1991.

25. Jensen R, Cruz DALM, Tesoro MG, Lopes MHBM. Translation and cultural adaptation for Brazil of the Developing Nurses' Thinking model. Rev Latino Am Enfermagem. 2014;22(2):197-203.

26. Freitas NO, Caltran MP, Dantas RAS, Rossi LA. Tradução e adaptação transcultural do Perceived Stigmatization Questionnaire para vítimas de queimaduras no Brasil. Rev Esc Enferm USP. 2014;48(1):25-33.

27. Valera GG, Carezzato NL, Vale FA, Hortense P. Cultural adaptation of the scale Pain Assessment in Advanced Dementia - PAINAD to Brazil. Rev Esc Enferm USP. 2014;48(3):462-8.

28. Brasil. Ministério da Saúde; Conselho Nacional de Secretários de Saúde. Atenção Primária e Promoção da Saúde [Internet]. Brasília; 2007 [citado 2014 jun. 02]. Disponível em: http://bvsms.saude.gov.br/bvs/publicacoes/colec_progestores_livro8.pdf

29. Brasil. Ministério da Saúde; Secretaria de Atenção à Saúde, Departamento de Atenção Básica. Política Nacional de Atenção Básica [Internet]. Brasília; 2012 [citado 2012 nov. 26]. Disponível em: http://bvsms.saude.gov.br/bvs/publicacoes/pnds_crianca_mulher.pdf

Funding: Fundação de Amparo à Pesquisas do Estado de São Paulo - FAPESP (Process number 2013/04915-3).

\section{APPENDIX: ORIGINAL VERSION OF THE INSTRUMENTS}

Chart 1 - Brazilian version of the guidelines for use of the instrument originally known as Atenció Sanitària de Les Demències: la visió de L'Atenció Primarià, for doctors and nurses.

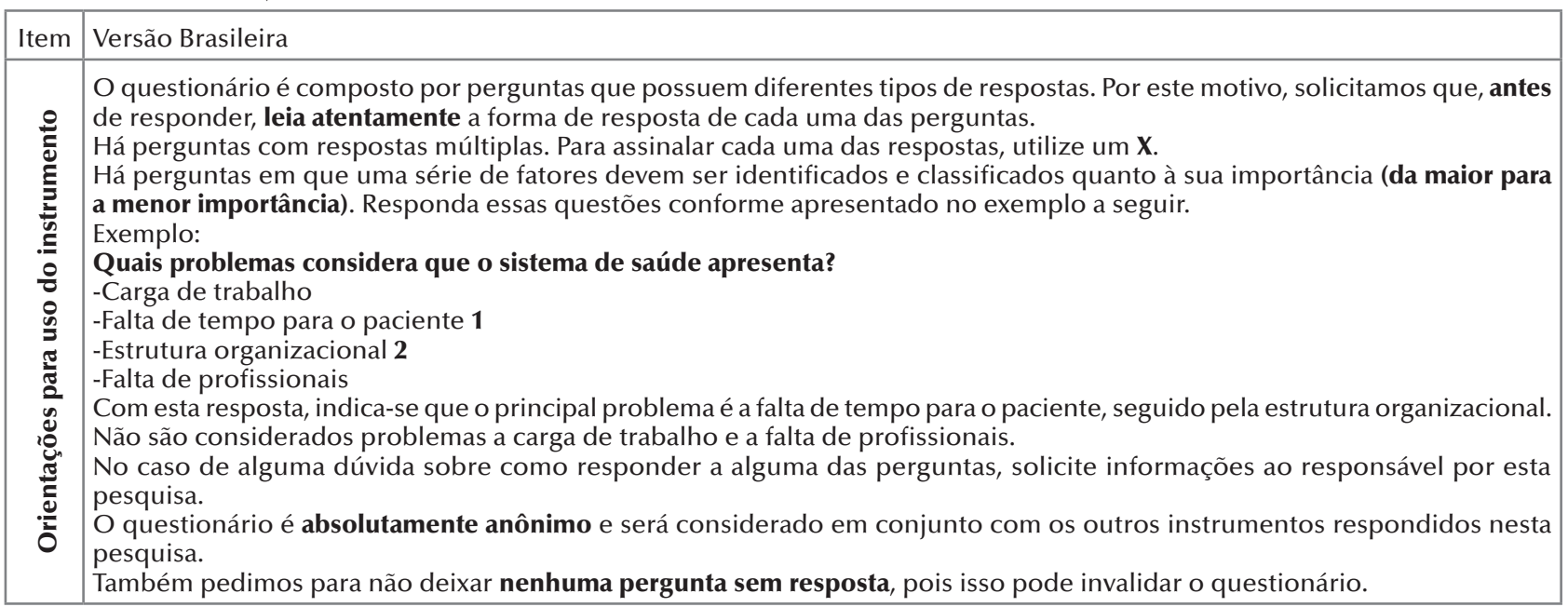

Chart 2 - Brazilian version of the instrument originally known as Atenció Sanitària de Les Demències: la visió de L'Atenció Primarià, for doctors.

\begin{tabular}{|c|c|c|}
\hline Item & Versão Brasileira & Respostas \\
\hline Questão 1 & Em que ano você nasceu? & - \\
\hline Questão 2 & $\begin{array}{l}\text { Onde você realizou o curso de Graduação } \\
\text { em Medicina? }\end{array}$ & $\begin{array}{l}\text {-Brasil } \\
\text {-Outro país (especifique): }\end{array}$ \\
\hline Questão 3 & Sexo & $\begin{array}{l}\text {-Masculino } \\
\text {-Feminino }\end{array}$ \\
\hline Questão 4 & $\begin{array}{l}\text { Quanto tempo de experiência de trabalho } \\
\text { você tem na Atenção Básica? }\end{array}$ & - \\
\hline Questão 5 & $\begin{array}{l}\text { Há quanto tempo você trabalha nesta } \\
\text { unidade da Atenção Básica? }\end{array}$ & Desde: \\
\hline
\end{tabular}

continued... 


\begin{tabular}{|c|c|c|}
\hline \multicolumn{3}{|l|}{..continuation } \\
\hline Item & Versão Brasileira & Respostas \\
\hline Questão 6 & $\begin{array}{l}\text { Você considera necessário realizar atividades } \\
\text { de capacitação específica em demência? }\end{array}$ & \begin{tabular}{|l|l|}
-Sim \\
-Não
\end{tabular} \\
\hline Questão 7 & $\begin{array}{l}\text { Você tem participado de atividades de } \\
\text { capacitação específica sobre o diagnóstico } \\
\text { e o tratamento da demência? }\end{array}$ & $\begin{array}{l}\text {-Não, nunca } \\
\text {-Sim, no último ano } \\
\text {-Sim, entre } 2 \text { e } 4 \text { anos atrás } \\
\text {-Sim, há } 5 \text { anos ou mais }\end{array}$ \\
\hline Questão 8 & $\begin{array}{l}\text { Qual é o percentual aproximado de } \\
\text { pessoas com } 60 \text { anos ou mais entre os seus } \\
\text { pacientes? }\end{array}$ & $\begin{array}{l}-<5 \% \\
-5-9 \% \\
-10-14 \% \\
-15-19 \% \\
-20-24 \% \\
->=25 \%\end{array}$ \\
\hline Questão 9 & $\begin{array}{l}\text { Com que frequência você faz diagnóstico } \\
\text { de demência? }\end{array}$ & $\begin{array}{l}\text {-Nunca } \\
\text {-Raramente } \\
\text { - Às vezes } \\
\text {-Frequentemente }\end{array}$ \\
\hline Questão 10 & $\begin{array}{l}\text { Nos últimos } 12 \text { meses, aproximadamente, } \\
\text { quantos casos de demência você detectou? }\end{array}$ & $\begin{array}{l}\text {-Nenhum } \\
\text {-Entre } 1 \text { e } 4 \\
\text {-Entre } 5 \text { e } 9 \\
\text {-Entre } 10 \text { e } 14 \\
\text {-Entre } 15 \text { e } 20 \\
\text {-20 ou mais }\end{array}$ \\
\hline Questão 11 & $\begin{array}{l}\text { Qual é o número aproximado de consultas } \\
\text { que você realiza por mês para pacientes } \\
\text { com demência? }\end{array}$ & $\begin{array}{l}- \text { Nenhum } \\
\text {-Entre } 1 \text { e } 4 \\
\text {-Entre } 5 \text { e } 9 \\
\text {-Entre } 10 \text { e } 14 \\
\text {-Entre } 15 \text { e } 20 \\
\text {-20 ou mais }\end{array}$ \\
\hline Questão 12 & $\begin{array}{l}\text { Em qual fase da demência você diagnostica } \\
\text { mais frequentemente seus pacientes? }\end{array}$ & $\begin{array}{l}\text {-Leve } \\
\text {-Moderada } \\
\text {-Grave } \\
\text {-Não diagnostico, encaminho ao especialista }\end{array}$ \\
\hline Questão 13 & $\begin{array}{l}\text { Quais são as dificuldades que você } \\
\text { encontra para identificar um caso de } \\
\text { demência? (selecione e ordene somente } \\
\text { aquelas que são uma dificuldade para } \\
\text { você, da maior para a menor dificuldade) }\end{array}$ & $\begin{array}{l}\text {-Diferenciar os sinais e sintomas de demência do envelhecimento normal } \\
\text {-Diferenciar os sinais e sintomas da demência da depressão geriátrica } \\
\text {-Pouca confiabilidade dos testes de memória } \\
\text {-Pouca utilidade dos exames complementares (neuroimagem e/ou laboratoriais) } \\
\text {-Outras (especifique): } \\
\text {-Não tenho dificuldades para identificar um caso de demência }\end{array}$ \\
\hline Questão 14 & $\begin{array}{l}\text { Quais os sinais e sintomas que levam } \\
\text { você a suspeitar de um diagnóstico de } \\
\text { demência? (selecione e ordene somente } \\
\text { aqueles que você utiliza, da maior para a } \\
\text { menor importância) }\end{array}$ & $\begin{array}{l}\text {-Sintomas psicológicos e comportamentais das demências (depressão, delírios, } \\
\text { agitação, alterações de personalidade, etc.) } \\
\text {-Comprometimento cognitivo com alterações de memória } \\
\text {-Comprometimento cognitivo sem alterações de memória } \\
\text {-Comprometimento da capacidade de executar atividades da vida diária (AVDs) } \\
\text {-Outros (especifique): }\end{array}$ \\
\hline Questão 15 & $\begin{array}{l}\text { Quais são os aspectos que dificultam você } \\
\text { no momento de realizar um diagnóstico de } \\
\text { demência? (selecione e ordene somente } \\
\text { aqueles que dificultam você, da maior para } \\
\text { a menor importância) }\end{array}$ & $\begin{array}{l}\text {-Pouca confiança sobre o diagnóstico (dúvidas quanto ao paciente realmente } \\
\text { ter uma demência) } \\
\text {-Pensar que o diagnóstico deve ser feito pelo serviço especializado } \\
\text {-Pouca utilidade do diagnóstico (não traz benefício nenhum para o paciente) } \\
\text {-Efeito negativo do diagnóstico sobre o paciente } \\
\text {-Efeito negativo do diagnóstico no ambiente familiar e social do paciente } \\
\text {-Dificuldades em dar más notícias } \\
\text {-Falta de tempo para realizaro processo de diagnóstico (aplicartestes, análises, etc.) } \\
\text {-Outros (especifique): } \\
\text {-Nenhum aspecto me dificulta, tento diagnosticar todos os casos detectados }\end{array}$ \\
\hline Questão 16 & $\begin{array}{l}\text { Com base na lista a seguir, de testes para } \\
\text { avaliar a função cognitiva e a capacidade } \\
\text { funcional, quais você utiliza habitualmente } \\
\text { em sua prática clínica? (selecione e ordene } \\
\text { somente aqueles que você utiliza, da maior } \\
\text { para a menor utilização) }\end{array}$ & $\begin{array}{l}\text { Função Cognitiva } \\
\text {-Miniexame do estado mental } \\
\text {-Avaliação cognitiva-funcional global (CDR) } \\
\text {-Teste de fluência verbal categoria animal e/ou frutas } \\
\text {-MOCA } \\
\text {-Lista de palavras do CERAD } \\
\text {-Teste de nomeação de Boston } \\
\text {-Teste do desenho do relógio } \\
\text {-Questionário de avaliação do comprometimento cognitivo do idoso por } \\
\text { informante (IQCODE) } \\
\text {-Inventário Neuropsiquiátrico } \\
\text {-Escala isquêmica de Hachinski } \\
\text {-Outros (especifique): } \\
\text {-Habitualmente não utilizo nenhum teste para avaliar a função cognitiva } \\
\text { Capacidade Funcional } \\
\text {-Teste de Pfeffer } \\
\text {-Índice de Katz } \\
\text {-Teste de Lawton } \\
\text {-Índice de Barthel } \\
\text {-Outros (especifique): } \\
\text {-Habitualmente não utilizo nenhum teste para avaliar a capacidade funcional }\end{array}$ \\
\hline
\end{tabular}




\begin{tabular}{|c|c|c|}
\hline Item & Versão Brasileira & Respostas \\
\hline Questão 17 & $\begin{array}{l}\text { Quais exames complementares você } \\
\text { solicita habitualmente para realizar o } \\
\text { diagnóstico do subtipo de demência? } \\
\text { (ex.: Alzheimer, demência vascular, etc.) } \\
\text { (resposta múltipla, selecione todos os } \\
\text { testes solicitados em sua prática clínica) }\end{array}$ & $\begin{array}{l}\text {-Hemograma } \\
\text {-Bioquímica com glicemia } \\
\text {-Enzimas hepáticas } \\
\text {-Coagulograma } \\
\text {-TSH } \\
\text {-Vitamina B } 12 \\
\text {-Ácido fólico } \\
\text {-Sorologia para HIV } \\
\text {-Sorologia para sífilis } \\
\text {--unção renal } \\
\text {-Cálcio } \\
\text {-Fósforo } \\
\text {-Eletrocardiograma } \\
\text {-Eletroencefalograma } \\
\text {-Tomografia computadorizada do crânio } \\
\text {-Ressonância magnética do crânio } \\
\text { - -Tomografia por emissão única de fótons - SPECT } \\
\text {-PET } \\
\text {-Espectroscopia por ressonância magnética do crânio } \\
\text {-Punção lombar } \\
\text {-Punção lombar com dosagem das proteínas características da doença de } \\
\text { Alzheimer } \\
\text {-Outros (especifique): } \\
\text {-Não faço o diagnóstico do subtipo de demência, encaminho para um especialista }\end{array}$ \\
\hline Questão 18 & $\begin{array}{l}\text { Com qual frequência você informa o } \\
\text { diagnóstico de demência? }\end{array}$ & $\begin{array}{l}\text { Ao paciente: } \\
\text {-Nunca } \\
\text {-Raramente } \\
\text {-Âs vezes } \\
\text {-Frequentemente } \\
\text { Aos familiares: } \\
\text {-Nunca } \\
\text {-Raramente } \\
\text {-Ãs vezes } \\
\text {-Frequentemente }\end{array}$ \\
\hline Questão 19 & $\begin{array}{l}\text { Quais são os fatores que mais têm } \\
\text { influência para você não informar ao } \\
\text { paciente que ele sofre de uma demência? } \\
\text { (selecione e ordene somente aqueles que } \\
\text { influenciam você, da maior para a menor } \\
\text { influência) }\end{array}$ & $\begin{array}{l}\text {-Estar em um estágio avançado da doença } \\
\text {-Ter mais de } 80 \text { anos } \\
\text {-Nãoter capacidade suficiente para compreender a informação sobreo diagnóstico } \\
\text {-Possibilidadedeodiagnósticoprovocar efeitos negativos sobreohumordopaciente } \\
\text {-Possibilidade de o diagnóstico provocar efeitos negativos sobre a vida diária } \\
\text { do paciente } \\
\text {-A família não querer que o paciente conheça o diagnóstico } \\
\text { - A impossibilidade de realizar um tratamento farmacológico específico } \\
\text { - Não existe nenhum fator que me influencie, sempre informo ao paciente e à } \\
\text { família sobre o diagnóstico de demência }\end{array}$ \\
\hline Questão 20 & $\begin{array}{l}\text { Em sua programação diária, você } \\
\text { habitualmente programa visitas } \\
\text { domiciliárias para tratamento e } \\
\text { acompanhamento de pacientes com } \\
\text { demência? }\end{array}$ & -Sim \\
\hline Questão 21 & $\begin{array}{l}\text { Você encontra dificuldades para cuidar de } \\
\text { pacientes com demência grave? }\end{array}$ & $\begin{array}{l}\text {-Sim (vá para a questão 21a) } \\
\text {-Não (vá para a questão 22) }\end{array}$ \\
\hline Questão 21a & $\begin{array}{l}\text { Por quais motivos? (resposta múltipla, } \\
\text { selecione todos os motivos que você } \\
\text { considerar) }\end{array}$ & $\begin{array}{l}\text {-O tratamento farmacológico é complexo } \\
\text {-Exigem muitas visitas domiciliárias } \\
\text {-Não há suporte de atendimento especializado } \\
\text {-Suas demandas não são solucionáveis na Atenção Básica }\end{array}$ \\
\hline Questão 22 & $\begin{array}{l}\text { Com qual frequência você costuma } \\
\text { planejar acompanhamento específico para } \\
\text { o cuidador do paciente com demência? }\end{array}$ & $\begin{array}{l}\text {-Nunca } \\
\text {-Raramente } \\
\text {-Äs vezes } \\
\text {-Frequentemente }\end{array}$ \\
\hline Questão 23 & $\begin{array}{l}\text { Em sua opinião, quais são as principais } \\
\text { dificuldades para o tratamento e o } \\
\text { acompanhamento dos pacientes com } \\
\text { demência na Atenção Básica? (selecione } \\
\text { e ordene somente aquelas que você } \\
\text { considerar como dificuldade, da maior } \\
\text { para a menor importância) }\end{array}$ & $\begin{array}{l}\text {-O tratamento com fármacos específicos (anticolinesterásicos e/ou memantina) } \\
\text {-O tratamento farmacológico com antidepressivos } \\
\text {-O tratamento farmacológico com antipsicóticos (típicos ou atípicos) } \\
\text {-O tratamento farmacológico com sedativos, benzodiazepínicos e hipnóticos } \\
\text {-Otratamentofarmacológicodarigidez, dotremoredeoutrosdistúrbiosneurológicos } \\
\text { - As necessidades de apoio do cuidador e/ou da família } \\
\text {-O acompanhamento e o tratamento do paciente com demência requer uma } \\
\text { grande quantidade de tempo, não disponível na Atenção Básica } \\
\text {-Não encontro dificuldade nenhuma em realizar o acompanhamento e o } \\
\text { tratamento dos pacientes com demência }\end{array}$ \\
\hline Questão 24 & $\begin{array}{l}\text { Quando você planeja o encaminhamento } \\
\text { de pacientes para diagnóstico e/ } \\
\text { ou controle, quais serviços médicos } \\
\text { especializados existem na sua área de } \\
\text { referência? (resposta múltipla, selecione } \\
\text { todas as respostas aplicáveis) }\end{array}$ & $\begin{array}{l}\text {-AME } \\
\text {-Ambulatório de Especialidades em Demências } \\
\text {-Centro de Referência do Idoso } \\
\text {-Serviço de neurologia hospitalar } \\
\text {-Neurologista de referência } \\
\text { - Outros (especifique): }\end{array}$ \\
\hline
\end{tabular}




\begin{tabular}{|c|c|c|}
\hline Item & Versão Brasileira & Respostas \\
\hline Questão 25 & $\begin{array}{l}\text { Em porcentagem, quantos pacientes } \\
\text { com demência você encaminha aos } \\
\text { serviços especializados para confirmar o } \\
\text { diagnóstico? }\end{array}$ & $\begin{array}{l}-<10 \% \\
-11-25 \% \\
-26-50 \% \\
-51-75 \% \\
->75 \% \\
- \text { Não encaminho nenhum caso de demência aos serviços especializados }\end{array}$ \\
\hline Questão 26 & $\begin{array}{l}\text { Em porcentagem, quantos pacientes com } \\
\text { demência você encaminha aos serviços } \\
\text { especializados para controle de distúrbios } \\
\text { comportamentais? }\end{array}$ & $\begin{array}{l}-<10 \% \\
-11-25 \% \\
-26-50 \% \\
-51-75 \% \\
->75 \% \\
- \text { Não encaminho nenhum caso de demência aos serviços especializados }\end{array}$ \\
\hline Questão 27 & $\begin{array}{l}\text { Dê pontuação ao seu nível de satisfação } \\
\text { (de } 1 \text { a 10) referente aos serviços médicos } \\
\text { especializados em relação aos casos de } \\
\text { demência que encaminhou (1 significa a } \\
\text { mínima satisfação possível e } \underline{10 \text { a máxima }} \\
\text { satisfação possível) }\end{array}$ & $\begin{array}{l}\text {-Tempo de espera desde a solicitação de visita até a visita ao paciente } \\
\text {-Devolução de informações ao serviço de Atenção Básica } \\
\text {-Capacidade de solucionar } \\
\text {-Acompanhamento do paciente } \\
\text {-Acessibilidade do serviço em situações de emergência } \\
\text {-Não encaminhei nenhum caso de demência aos serviços especializados }\end{array}$ \\
\hline Questão 28 & $\begin{array}{l}\text { Caso clínico } \\
\text { Imagine que você está no seu consultório } \\
\text { e observa que na sala de espera está o Sr. } \\
\text { João ( } 71 \text { anos de idade), sentado com a } \\
\text { esposa dele. Você se aproxima dele e o } \\
\text { cumprimenta, mas percebe que ele não o } \\
\text { reconhece. Ainda que tenha sido o médico } \\
\text { dele nos últimos } 15 \text { anos e que até há } \\
\text { um ano o Sr. João ajudava no açougue da } \\
\text { esposa dele, onde você geralmente faz } \\
\text { compras, ele só o reconheceu quando a } \\
\text { esposa explicou quem você era. A esposa } \\
\text { informa que veio ao consultório porque nos } \\
\text { últimos meses o Sr. João tem demonstrado } \\
\text { alguns problemas de memória, tem } \\
\text { esquecido onde deixa suas coisas, tem } \\
\text { tido problemas para lidar com as contas da } \\
\text { casa, tem estado triste e, em determinada } \\
\text { ocasião, ficou desnorteado com o carro } \\
\text { quando voltavam para a casa por uma rua } \\
\text { conhecida. A esposa dele comenta que } \\
\text { teme que o Sr. João tenha Alzheimer. } \\
\text { Após realizar o estudo e diagnosticar a } \\
\text { doença de Alzheimer no Sr. João, indique } \\
\text { o nílel de recomendação das intervençôes } \\
\text { a seguir: } \\
\text { Indique o nível de recomendação para } \\
\text { cada intervenção conforme a seguinte } \\
\text { codificação numérica } \\
\text { Nunca [1] } \\
\text { Quase nunca [2] } \\
\text { Poucas vezes [3] } \\
\text { Algumas vezes [4] } \\
\text { Quase sempre [5] } \\
\text { Sempre [6] }\end{array}$ & $\begin{array}{l}\text { Não recomendaria: } \\
\text {-Vitaminas } \\
\text {-Tratamentos naturais/ervas } \\
\text {-Remédios anticolinesterásicos } \\
\text {-Memantina } \\
\text {-Antidepressivos tricíclicos } \\
\text {-Antidepressivos ISRS } \\
\text {-Antipsicóticos típicos } \\
\text {-Antipsicóticos atípicos } \\
\text { Recomendaria: } \\
\text {-Exercícios de memória (gerais) } \\
\text {-Estimulação cognitiva (específica) } \\
\text {-Musicoterapia, aromaterapia } \\
\text {-Assistência em um centro dia para idosos } \\
\text {-Ingresso em uma instituição de longa permanência } \\
\text {-Encaminhamento a um especialista } \\
\text {-Visita de um(a) assistente social } \\
\text {-Associação de familiares de pacientes com Alzheimer } \\
\end{array}$ \\
\hline
\end{tabular}

Chart 3 - Brazilian version of the instrument originally known as Atenció Sanitària de Les Demències: la visió de L' Atenció Primarià, for nurses.

\begin{tabular}{|c|c|c|}
\hline Item & Versão Brasileira & Respostas \\
\hline Questão 1 & Em que ano você nasceu? & - \\
\hline Questão 2 & $\begin{array}{l}\text { Onde você realizou o curso de Graduação em } \\
\text { Enfermagem? }\end{array}$ & $\begin{array}{l}\text {-Brasil } \\
\text {-Outro país (especifique): }\end{array}$ \\
\hline Questão 3 & Sexo & $\begin{array}{l}\text {-Masculino } \\
\text {-Feminino }\end{array}$ \\
\hline Questão 4 & 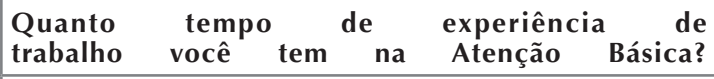 & - \\
\hline Questão 5 & $\begin{array}{l}\text { Há quanto tempo você trabalha nesta unidade da Atenção } \\
\text { Básica? }\end{array}$ & Desde:_/_ \\
\hline Questão 6 & $\begin{array}{l}\text { Você considera necessário realizar atividades de } \\
\text { capacitação específica em demência? }\end{array}$ & $\begin{array}{l}\text {-Sim } \\
\text {-Não }\end{array}$ \\
\hline Questão 7 & $\begin{array}{l}\text { Você tem participado de atividades de capacitação } \\
\text { específica em demência? }\end{array}$ & $\begin{array}{l}\text {-Não, nunca } \\
\text {-Sim, no último ano } \\
\text {-Sim, entre } 2 \text { e } 4 \text { anos atrás } \\
\text {-Sim, há } 5 \text { anos ou mais }\end{array}$ \\
\hline
\end{tabular}




\begin{tabular}{|c|c|c|}
\hline Item & Versão Brasileira & Respostas \\
\hline Questão 8 & $\begin{array}{l}\text { Qual é o percentual aproximado de pessoas com } 60 \text { anos } \\
\text { ou mais entre os seus pacientes? }\end{array}$ & $\begin{array}{l}-<5 \% \\
-5-9 \% \\
-10-14 \% \\
-15-19 \% \\
-20-24 \% \\
->=25 \%\end{array}$ \\
\hline Questão 9 & $\begin{array}{l}\text { Nos últimos } 12 \text { meses, aproximadamente, quantos novos } \\
\text { casos de demência você atendeu durante a consulta de } \\
\text { enfermagem? }\end{array}$ & $\begin{array}{l}- \text {-Nenhum } \\
\text {-Entre } 1 \text { e } 4 \\
\text {-Entre } 5 \text { e } 9 \\
\text {-Entre } 10 \text { e } 14 \\
\text {-Entre } 15 \text { e } 20 \\
\text {-20 ou mais }\end{array}$ \\
\hline Questão 10 & $\begin{array}{l}\text { Qual é o número aproximado de consultas que você } \\
\text { realiza por mês para pacientes com demência? }\end{array}$ & $\begin{array}{l}\text {-Nenhum } \\
\text {-Entre } 1 \text { e } 4 \\
\text {-Entre } 5 \text { e } 9 \\
\text {-Entre } 10 \text { e } 14 \\
\text {-Entre } 15 \text { e } 20 \\
\text {-20 ou mais }\end{array}$ \\
\hline Questão 11 & $\begin{array}{l}\text { Quais são os sinais e os sintomas que você utiliza } \\
\text { como base para suspeitar de uma possível demência e } \\
\text { encaminhar o paciente para o médico? (selecione e ordene } \\
\text { somente aqueles que você utiliza, da maior para a menor } \\
\text { importância) }\end{array}$ & $\begin{array}{l}\text {-Sintomas psicológicos e comportamentais das demências } \\
\text { (depressão, delírios, agitação, alterações de personalidade, etc.) } \\
\text {-Comprometimento cognitivo com alterações de memória } \\
\text {-Comprometimento cognitivo sem alterações de memória } \\
\text {-Comprometimento da capacidade de executar atividades da } \\
\text { vida diária (AVDs) } \\
\text {-Outros (especifique): }\end{array}$ \\
\hline Questão 12 & $\begin{array}{l}\text { Com base na lista a seguir, de testes para avaliar a função } \\
\text { cognitiva e a capacidade funcional, quais você utiliza } \\
\text { habitualmente em sua prática clínica? (selecione e ordene } \\
\text { somente aqueles que você utiliza, da maior para a menor } \\
\text { utilização) }\end{array}$ & $\begin{array}{l}\text { Função Cognitiva } \\
\text {-Miniexame do estado mental } \\
\text {-Avaliação cognitiva-funcional global (CDR) } \\
\text {-Teste de fluência verbal categoria animal e/ou frutas } \\
\text {-MOCA } \\
\text {-Lista de palavras do CERAD } \\
\text { - Teste de nomeação de Boston } \\
\text { - Teste do desenho do relógio } \\
\text {-Questionário de avaliação do comprometimento cognitivo do } \\
\text { idoso por informante (IQCODE) } \\
\text {-Inventário Neuropsiquiátrico } \\
\text {-Escala isquêmica de Hachinski } \\
\text {-Outros (especifique): } \\
\text {-Habitualmente não utilizo nenhum teste para avaliar a função } \\
\text { cognitiva } \\
\text { Capacidade Funcional } \\
\text {-Teste de Pfeffer } \\
\text {-Índice de Katz } \\
\text {-Teste de Lawton } \\
\text {-Índice de Barthel } \\
\text {-Outros (especifique): } \\
\text {-Habitualmente não utilizo nenhum teste para avaliar a } \\
\text { capacidade funcional }\end{array}$ \\
\hline Questão 13 & $\begin{array}{l}\text { Em sua programação diária, você habitualmente programa } \\
\text { visitas domiciliárias para acompanhamento de pacientes } \\
\text { com demência? }\end{array}$ & $\begin{array}{l}-\operatorname{Sim} \\
-\mathrm{Não}\end{array}$ \\
\hline Questão 14 & $\begin{array}{l}\text { Você encontra dificuldades para cuidar de pacientes com } \\
\text { demência grave? }\end{array}$ & $\begin{array}{l}\text {-Sim (vá para a questão 14a) } \\
\text {-Não (vá para a questão 15) }\end{array}$ \\
\hline Questão 14a & $\begin{array}{l}\text { Por quais motivos? (resposta múltipla, selecione todos os } \\
\text { motivos que você considerar) }\end{array}$ & $\begin{array}{l}\text {-Por serem pacientes difíceis } \\
\text {-Exigem muitas visitas domiciliárias } \\
\text {-Não há suporte de atendimento especializado } \\
\text {-Suas demandas não são solucionáveis na Atenção Básica }\end{array}$ \\
\hline Questão 15 & $\begin{array}{l}\text { Com qual frequência você costuma planejar } \\
\text { acompanhamento específico para o cuidador do paciente } \\
\text { com demência? }\end{array}$ & $\begin{array}{l}\text {-Nunca } \\
\text {-Raramente } \\
\text {-Às vezes } \\
\text {-Frequentemente }\end{array}$ \\
\hline Questão 16 & $\begin{array}{l}\text { Em sua opinião, quais são as funções que a equipe de } \\
\text { enfermagem deve desenvolver para acompanhamento de } \\
\text { pacientes com demência na Atenção Básica? (selecione } \\
\text { e ordene todas as que você considerar, da maior para a } \\
\text { menor importância) }\end{array}$ & $\begin{array}{l}\text {-Avaliação periódica do comprometimento cognitivo } \\
\text {-Avaliação periódica do comprometimento funcional } \\
\text {-Controle da(s) comorbidade(s) apresentada(s) pelo(a) paciente } \\
\text {-Controle da prescrição farmacológica e acompanhamento } \\
\text { terapêutico } \\
\text {-Avaliação de riscos no domicílio } \\
\text {-Realização de atividades de estimulação cognitiva } \\
\text {-Apoio às necessidades do cuidador e/ou da família } \\
\text {-Outras (especifique): }\end{array}$ \\
\hline
\end{tabular}

